\title{
A Comparative Study on Medicine Pricing in Brazil, Russia, India, China and South Africa (BRICS)
}

\author{
Varsha Bangalee $^{1} \&$ Fatima Suleman ${ }^{1}$ \\ ${ }^{1}$ Discipline of Pharmaceutical Sciences, School of Health Sciences, Westville Campus, University of \\ KwaZulu-Natal, Durban, South Africa \\ Correspondence: Varsha Bangalee, Discipline of Pharmaceutical Sciences, School of Health Sciences, Westville \\ Campus, University of KwaZulu-Natal, Durban, South Africa. Tel: 27-31-260-7908, E-mail: \\ bangalee@ukzn.ac.za
}

Received: May 30, 2018 Accepted: September 16, 2018 Online Published: September 28, 2018

doi:10.5539/gjhs.v10n10p152

URL: https://doi.org/10.5539/gjhs.v10n10p152

\begin{abstract}
Background: It is well documented that high prices hinder access to medicines to a large percentage of the population in low- and middle-income countries. It is with this in mind that governments have made attempts to control medicine pricing with the intent to protect and promote a country's overall health. BRICS as Brazil, Russia, India, China and South Africa have collectively become to be known, represent five newly emerging global economies, each one attempting to control medicine pricing and improve accessibility.
\end{abstract}

Objective: To compare the medicine pricing regulatory efforts made by each of the BRICS countries.

Method: This was achieved through the dissemination of an online survey posed to members of the BRICS Medicines Alliance. Questions in the survey looked at the presence of an essential's medicines list; pricing regulations and control measures employed at the manufacturer, wholesaler and retail level.

Results: The findings reveal that each country has adopted different paths and time frames toward policy and regulatory development.

Conclusion: Despite the variations in policy adoption, shared lessons can still be learnt from each country to improve the outcomes for each individual country and create an opportunity for pharmaceutical growth and transparency in medicine pricing.

Keywords: pricing policies, BRICS, medicine pricing

\section{Background}

It is well documented that high medicine prices contribute to a large percentage of the population lacking access to medicines in low- and middle-income countries (LMICs) (Cameron et al., 2009). Unaffordability can also be attributed to distortions of mark-ups along the supply chain, which amount to a significant cost driver to the final price of medicines (Ball, 2011). Thus, the pharmaceutical industry is often controlled by governments, with the intent to protect and promote a country's overall health, owing to the pivotal role medicines play in ensuring the safety of any population (Ball, 2011). Despite dramatic efforts on the part of several governments to rationalise, and develop policies to improve access to crucial medicines, several of these attempts fall short of attaining these objectives. Furthermore, lack of evidence and research on implemented policies, makes it difficult to measure effected outcomes.

BRICS as Brazil (upper-middle income), Russia (high income), India (lower-middle income), China (upper-middle income) and South Africa (upper-middle income) have collectively become to be known, came into establishment in 2010 (South Africa joining in 2011). They represent five newly emerging global economies and account for about $43 \%$ of the global population (Sun et al., 2014). The prospects of unified ideas and the proposed potential for improvements in various economic platforms has captured the attention of scholars worldwide. BRICS governments, who have since been collaborating toward shared socioeconomic objectives, have set their attention to collectively improve, innovate and strengthen access and use of medicines in their countries through shared research, knowledge and understanding. Despite their economic and cultural diversities, these nations are struggling with similar healthcare challenges, including access to health services and medicines, growing health costs, infectious diseases, such as HIV and tuberculosis, and the growing prevalence of non-communicable 
diseases (Sun et al., 2014).

Over the last two decades, BRICS have committed to health-system reforms with the ultimate goal of achieving universal health coverage (UHC) (Rao, Petrosyan, Araujo \& McIntyre, 2014). Each country varies in its diversity in adopting UHC and have initiated the process over different timelines. Brazil and Russia have embarked on this process over two decades ago, followed by China and India, who have started their reforms in the last decade (Rao, Petrosyan, Araujo \& McIntyre, 2014). India has rolled out its National Health Mission for UHC, while China has set itself the goal of achieving UHC by 2020 (Rao, Petrosyan, Araujo \& McIntyre, 2014). South Africa has only recently begun the reform process, publishing its White Paper in 2015 (Keeton, 2014). Sound medicine pricing regulations are essential to the reform process, as they protect public health by assuring the accessibility to safe, efficacious and quality medicines (Rägo \& Santoso, 2008). Similarly, drawing on lessons from previous collaborations, this articles aims to highlight several of the efforts pertaining to medicine pricing across the five BRICS nations.

\section{Methodology}

\subsection{Study Design}

This was an observation, questionnaire administered study. A web search was also conducted to draw comparisons of medicine pricing data across BRICS (search included data for the same medicine on the same day for all countries).

\subsection{Study Sample}

Five members of The BRICS Medicines Alliance research group were conveniently sampled to participate in the study. These individuals are active in their countries in terms of coordinating defined work and research activities which amongst other responsibilities pertain to the strengthening and improvement of medicine access. The profiles of these individuals as provided by the respondents are as follows:

Brazil - Researcher in the Nucleus for Pharmaceutical Policies, a department in the National School of Public Health. This group is a PAHO-WHO collaborating Centre on Pharmaceutical Policies since 1998.

Russia - Head of teaching Department at the Kazan Federal University.

India - Senior Health Specialist with the World Bank's Global Practice on Health, Nutrition and Population.

China - Associate Professor for Pharmaceutical Policy Dept of Nutrition, Food and Drug Safety School of Public Health Peking Union Medical College Chinese Academy of Medical Science

South Africa - Director at the directorate Pharmaceutical Economic Evaluations. Our responsibility entails implementing transparency policies in pricing of medicines registered in terms of the Medicines and Related Substances Act 101 of 1965 .

\subsection{Data Collection}

Empirical data for this study was obtained to determine the current regulations and policies operating in the five BRICS nations. Questions were mainly derived from a survey conducted by the Directorate for Financial and Enterprise Affairs on competition issues in the distribution of pharmaceuticals, designed to capture and compare information on BRICS regulatory operations in the pharmaceutical supply chain (Health Action International, 2010). Additionally a literature review on similar studies held around the world was conducted using electronic databases. This insight allowed for the development of a questionnaire that thoroughly explored the policies on logistics and pricing of medicines. Once the questionnaire was constructed, using the online program SurveyMonkey, academics from the Discipline of Pharmaceutical Sciences (University of KwaZulu Natal) provided feedback on the appropriateness of questions, layout, sequence and themes. The survey consisted of 32 questions in total. The first 7 questions were designed to obtain informed consent for participation and to collect respondent's demographic information. The remaining questions were developed to obtain information pertaining to pharmaceutical regulation and policy. This paper only reports on questions in the survey that looked at the presence of an essential's medicines list; pricing regulations and control measures employed at the manufacturer, wholesaler and retail level. The remaining questions were omitted at they did not fall within the scope of the thesis objectives, but derived responses have been consolidated to develop further publications. Most of the questions were close ended, however, respondents were given the opportunity to provide comments. The survey remained open from June 2015 - May 2016 until responses from all countries were obtained.

\subsection{Data Analysis}

An exploratory data analysis plan was used. The study reports and elaborates on the key findings that pertain to 
pricing regulations across all countries.

\subsection{Ethical Considerations}

Ethical approval for this study was obtained from the University of KwaZulu Natal Human and Social Sciences Ethics Committee (HSS/0154/013). Informed consent for participation was obtained from each respondent participating in the study.

\section{Results and Discussion}

Responses were received from all countries. Only 4 questionnaires were completely answered. India was partially answered. Key aspects of medicine pricing policies are summarised in Table 1.

Table 1. Responses from BRICS countries on key pricing issues

\begin{tabular}{|c|c|c|c|c|c|c|}
\hline & Question & Brazil & Russia & India & China & $\begin{array}{l}\text { South } \\
\text { Africa }\end{array}$ \\
\hline 1 & $\begin{array}{l}\text { Presence of an Essential } \\
\text { Medicines List? }\end{array}$ & Yes & Yes & Yes & Yes & Yes \\
\hline 2 & $\begin{array}{l}\text { Negotiating stakeholder } \\
\text { for medicine prices in the } \\
\text { private sector }\end{array}$ & Government negotiated & Government negotiated & $\begin{array}{l}\text { *Pharmacy } \\
\text { benefit schemes/ } \\
\text { health insurers } \\
\text { *Government } \\
\text { negotiated }\end{array}$ & $\begin{array}{l}\text { Pharmacy } \\
\text { benefit } \\
\text { schemes/ } \\
\text { health } \\
\text { insurers }\end{array}$ & $\begin{array}{l}\text { Governmen } \\
\text { t negotiated }\end{array}$ \\
\hline 3 & $\begin{array}{l}\text { Negotiating stakeholder } \\
\text { for medicine prices in the } \\
\text { public sector? }\end{array}$ & Government negotiated & Government negotiated & $\begin{array}{l}\text { Government } \\
\text { negotiated }\end{array}$ & $\begin{array}{l}\text { Government } \\
\text { negotiated }\end{array}$ & $\begin{array}{l}\text { Governmen } \\
\text { t negotiated }\end{array}$ \\
\hline 4 & $\begin{array}{l}\text { The use of free pricing as } \\
\text { a price setting tool for any } \\
\text { medicines }\end{array}$ & No & $\begin{array}{l}\text { Yes, which are not on the } \\
\text { National Essential } \\
\text { medicines list }\end{array}$ & Yes & $\begin{array}{l}\text { Yes, Off the } \\
\text { basic health } \\
\text { insurance } \\
\text { program }\end{array}$ & $\begin{array}{l}\text { Yes, } \\
\text { schedule } 0 \\
\text { and } \\
\text { veterinary } \\
\text { medicines }\end{array}$ \\
\hline
\end{tabular}

a. The use of trade

discounts by

manufacturers to a. Yes.

wholesalers
pharmacies?

5

b. Transparency of these

discounts are accessible in internet.

or b. All public purchasing a. Yes. Not necessarily easy to b. Not transparent find
a. Yes
b. No response
a. Yes
b. Not transparent

6

*Imposed maximum
prices/caps
*Cost of production plus
a profit margin (cost-plus
pricing)

Policies that exist to restrict medicine prices
*External reference price are used as info when Imposed maximum sales price is prices/caps agreed. There are taxes at state and municipality level, which impacts the actual retail price.

*Imposed maximum prices/caps
*Internal $\begin{array}{lll}\text { maximum } & * \text { Cost oference pricing } \\ \text { production plus a } & \begin{array}{l}\text { Internal } \\ \text { reference }\end{array} \\ \text { profit margin } & \text { pricing } \\ \text { (cost-plus pricing) } & \end{array}$ Single Exit Price (SEP) 


\begin{tabular}{|c|c|c|c|c|c|c|}
\hline 7 & $\begin{array}{l}\text { Pricing based on } \\
\text { pharmacoeconomic } \\
\text { assessments? }\end{array}$ & Yes & No & No & No & No \\
\hline 8 & $\begin{array}{l}\text { Government imposed } \\
\text { price controls on: } \\
\text { - Generic medicines } \\
\text { - Branded medicines } \\
\text { - Locally manufactured } \\
\text { medicines } \\
\text { - Presence on an } \\
\text { Essentials Medicines List } \\
\text { or other positive list } \\
\text { - Prescription medicines } \\
\text { Non-prescription } \\
\text { medicines } \\
\text { Please expand on your } \\
\text { answer choice }\end{array}$ & $\begin{array}{l}\text { Maximum sales price } \\
\text { depends on the innovation } \\
\text { level of the medicines. } \\
\text { Initial price for generics } \\
\text { must be at least } 35 \% \\
\text { lower the reference } \\
\text { medicine. }\end{array}$ & $\begin{array}{l}\text { Presence on an Essentials } \\
\text { Medicines List or other } \\
\text { positive list }\end{array}$ & $\begin{array}{l}\text { *Prescription } \\
\text { medicines } \\
\text { *Locally } \\
\text { manufactured } \\
\text { medicines } \\
\text { *Branded } \\
\text { medicines } \\
\text { *Generic } \\
\text { medicines }\end{array}$ & $\begin{array}{l}* \text { Generic } \\
\text { medicines } \\
* \text { Branded } \\
\text { medicines } \\
* \text { Locally } \\
\text { manufactured } \\
\text { medicines } \\
\text { *Presence on } \\
\text { an Essentials } \\
\text { Medicines } \\
\text { List or other } \\
\text { positive list } \\
\text { *Prescription } \\
\text { medicines }\end{array}$ & $\begin{array}{l}\text { No. All } \\
\text { medicines } \\
\text { in the } \\
\text { private } \\
\text { sector } \\
\text { regulated by } \\
\text { the SEP } \\
\text { with the } \\
\text { exception of } \\
\text { schedule } 0 \\
\text { and veterinary } \\
\text { medicines }\end{array}$ \\
\hline 9 & $\begin{array}{l}\text { Wholesale mark-ups are } \\
\text { regulated }\end{array}$ & Yes & No & Yes & Yes & $\begin{array}{l}\text { Fixed as } \\
\text { part of SEP }\end{array}$ \\
\hline
\end{tabular}

Prices are regulated in the wholesale market by:

-Maximum allowable mark-up

$\begin{array}{ll}\text { - Maximum allowable } & \begin{array}{l}* \text { Maximum allowable } \\ \text { mark-up }\end{array}\end{array}$

10 margin

-Maximum price for *Maximum price for resale/ regulated price cap resale/ regulated price cap

- Combination of these strategies

- Other (please specify)

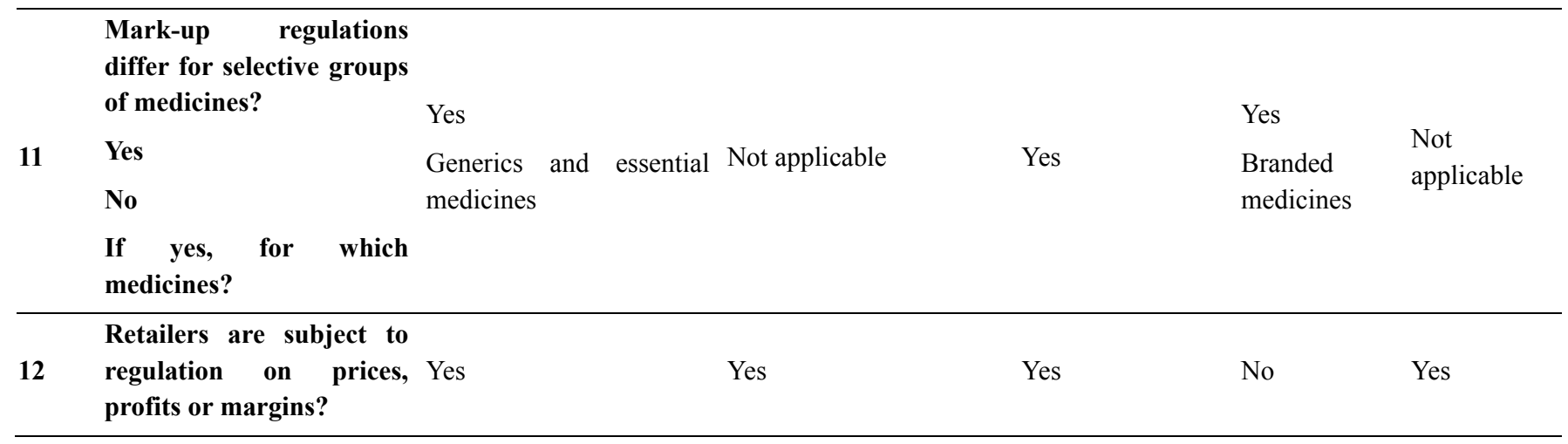


Profit margins are controlled in the retail sector by:

- Fixed margin

$\bullet$ Fixed percentage

- Regressive percentage

- Cap

- Other (please specify) $\begin{array}{lll} & \text { Cap } \\ \text { Fixed percentage } & \text { Fixed margin } & \text { Regressive fixed fee } \text { percentage }^{\text {Fixed }} \\ & & \text { Fixed margin }\end{array}$
Combinatio

$\mathrm{n}$ of $\mathrm{a}$ percentage of the SEP and a fixed fee

\begin{tabular}{|c|c|c|c|c|c|c|}
\hline 14 & $\begin{array}{l}\text { Regulations different for } \\
\text { medicines with different } \\
\text { patent status? }\end{array}$ & No & No & No & $\begin{array}{l}\text { Branded } \\
\text { medicines }\end{array}$ & No \\
\hline 15 & $\begin{array}{l}\text { Retail medicine price } \\
\text { information is publicly } \\
\text { accessible? }\end{array}$ & Yes & Yes & $\begin{array}{l}\text { Yes, through } \\
\text { databases } \\
\text { managed privately } \\
\text { such as MIMS and } \\
\text { Drug Today }\end{array}$ & Yes & Yes \\
\hline 16 & $\begin{array}{l}\text { Discounts are negotiated } \\
\text { with the wholesaler, which } \\
\text { determines the acquisition } \\
\text { cost of the medicine? }\end{array}$ & Yes & No & Yes & Yes & No \\
\hline 17 & $\begin{array}{l}\text { Dispensers are allowed to } \\
\text { charge a dispensing fee? } \\
\text { If answered Yes how is } \\
\text { this fee calculated? }\end{array}$ & No & $\begin{array}{l}\text { Yes } \\
\text { Fixed percentage }\end{array}$ & No & No & $\begin{array}{l}\text { Yes } \\
\text { Percentage } \\
\text { and fixed } \\
\text { amount }\end{array}$ \\
\hline 18 & $\begin{array}{l}\text { Presence of regulations } \\
\text { prohibiting rebates/ } \\
\text { bonuses/sampling? }\end{array}$ & $\begin{array}{l}\text { No, We have specific } \\
\text { regulation for sampling. } \\
\text { They are only allowed to } \\
\text { OTC medicines. }\end{array}$ & No & No & Yes & Yes \\
\hline 19 & $\begin{array}{l}\text { Government } r \\
\text { policies/mechanisms } \\
\text { actively monitor retail } \\
\text { pricing? }\end{array}$ & $\begin{array}{l}\text { No. Some } \\
\text { implementation, in } \\
\text { partnership with IMS } \\
\text { Health and some } \\
\text { consumer } \\
\text { NGOs protection }\end{array}$ & $\begin{array}{l}\text { Yes. Special monitoring } \\
\text { programs }\end{array}$ & No & Yes & No \\
\hline
\end{tabular}

The search for pricing data yielded the results displayed in Table 2.

Table 2. Average price of a $10 \mathrm{ml}$ vial of $100 \mathrm{IU} / \mathrm{ml}$ soluble human insulin

\begin{tabular}{lll}
\hline Country & $\begin{array}{l}\text { Average price reported from cities/towns } \\
\text { for Eli Lilly Product (US\$) }\end{array}$ & $\begin{array}{l}\text { Average price reported from cities/towns for Novo } \\
\text { Nordisk Product (US\$) }\end{array}$ \\
\hline Brazil & 22.91 & 21.49 \\
India & 4.99 & 3.45 \\
South Africa & 53.53 & 33.19 \\
\hline
\end{tabular}

Private sector prices were obtained from retail pharmacies for a $10 \mathrm{ml}$ vial of $100 \mathrm{IU} / \mathrm{ml}$ soluble human insulin (neutral, regular), manufactured by either Eli Lilly or Novo Nordisk. This survey was conducted by Health Action 
International (HAI) in collaboration with the World Health Organisation (WHO), on May 11, 2010, to gain a one-day snap shot of a medicine price across 93 countries (Bertoldi et al., 2012). China and Russia did not partake in the survey. The results reveal the considerable difference in prices between all 3 countries, with India achieving the lowest prices for both products.

The remainder of the results and discussion, continues with a description of various features of the pricing regulations for each of the five countries.

\subsection{Brazil}

The Brazilian Universal Health System (SUS) is a single publicly funded system that aims to freely distribute essential medicines used to treat the country's most prevalent diseases to its entire population (Rao, Petrosyan, Araujo \& McIntyre, 2014; PricewaterhouseCoopers, 2013).

In Brazil, direct control over medicine prices are stringently exercised and administered by the Câmara de Regulação do Mercado de Medicamentos (CMED). Medicine prices are set by CMED, after gaining marketing authorization from the National Health Surveillance Agency (ANVISA). The exception being in the case of new presentation forms and generic drugs, where companies can immediately start marketing the product. The CMED is tasked with determining the maximum product price, annual price adjustments and with ensuring that the industry complies with these resolutions (EMIS, 2014). The annual adjustment is calculated, using the Amplified Consumer Price Index and is set in three different ranges according to the type of drug; level of competition of medicines on the market and the share of generics in sales. Only over-the counter (OTC) drugs are exempt from mandatory annual price adjustments (Ultrapar, 2016).

Regulation of prices and policies in the retail sector is shared between the Brazilian government, the state governments and municipalities. Government enacts laws and regulations of general applicability, which are enforced and complemented by actions of the state governments and municipalities (Vashisth, Singh, \& Nanda, 2012). The government further annually approves maximum wholesale and consumer price adjustments of medicines, according to a metric that includes inflation and the level of competition in each product category (Vashisth, Singh, \& Nanda, 2012).

Brazil, is the only BRICS country that formally utilizes pharmacoeconomic evaluations to influence medicine pricing decisions, and has a well-established centralized drug regulatory system, similar to the United States of America (IMS Health, 2015). Once a new drug or new pharmaceutical presentation gains marketing authorization, companies are required to submit related economic data on the product and propose a suggested price (EMIS, 2014). External reference pricing (ERP) is used to define the price of new medicines. The manufacturer's price in Brazil may not exceed the lowest price charged in nine different countries i.e. United States, New Zealand, Australia, Greece, Portugal, Italy, Spain, France, Canada and possibly the country of origin (Kohler et al., 2015). The law mandates that generic medicine prices should be at least 35\% lower than the corresponding reference drug prices and be pre-approved by a government drug committee. Owing to generic market competition, many companies have used more aggressive discount policies that average $50 \%$, reaching $70-80 \%$ in some cases (IMS Health, 2015). CMED fixes a price cap for sales from pharmaceutical companies to their distributors, and for final sales to consumers (Kohler et al., 2015).

In an effort to improve good governance and reduce the corruption in pharmaceutical procurement (often experienced through collusion in bidding, "fixed" procurement bidding and kickbacks to public officials in order to gain support for a bid) Brazil had introduced measures to improve pricing transparency (Bertoldi et al., 2012). The Brazilian market is oligopolistic with few competitors that are capable of increasing medicine prices owing to the informational asymmetry that exists between themselves and their purchasers. Hence government has made it mandatory to report procurement pricing information via an open access online information system, as a transparency measure to facilitate the centralization of pricing information, and to decrease the high cost of medicines and medical supplies (Bertoldi et al., 2012).

A Brazilian pricing, availability and affordability study considered the differences of these factors across three types of medicines (originator brands, generics and similar medicines) and different types of facilities in both the public and private sectors (Deloitte, 2015). Findings indicated that for all medicines, prices in Brazil were higher than international reference prices. Furthermore, poor availability of generics or similar medicines in the public sector, consequently, meant that patients would made out-of-pocket payments in the private sector, where prices are higher, thus impacting affordability. The study also noted that despite the initial decrease in medicine prices brought about by regulations instituted by ANVISA, prices could be further reduced, by lowering taxes on medicines. It was found that on average $36 \%$ of the price paid for medicines in the country went to the government 
due to taxes along the supply chain, and thus represents an area that requires more regulation.

\subsection{Russia}

Russia's reform toward UHC has been established though a system of mandatory health insurance. The health sector is predominantly financed through general taxes, with payroll taxation employed as a complementary source of funding (Rao, Petrosyan, Araujo, \& McIntyre, 2014).

Pharmaceutical pricing regulations are currently applied to two lists, namely the reimbursement list (in which prices are set by auction) and the vital and essential drug list (VED) (which accounts for about one third of the retail pharma market) (Vitale, 2014). The process is state controlled and subject to state registration and mark-up regulations. Controls include maximum ex-manufacturer prices; determination of maximum wholesale and maximum retail mark-ups to the actual ex-manufacturer price for the medicinal products included in the list (Health Action International, 2010).

The VED list is revised and re-approved annually, with the ex-manufacturer's maximum price registered on a mandatory basis (the calculation methodology being different for local and imported drugs); and wholesale and retail trade mark-ups being established at the regional level (Pharmaceutical Market Assessment, 2013). According to federal legislation, the maximum mark-up over the ex-manufacturer's price is $25 \%$, and retail prices should not exceed wholesale prices by more than $30 \%$ for medicines included in the list of essential drugs (Zasimova, 2010). In practice, the mark-ups within these limits are the responsibility of regional authorities and therefore vary from region to region (Tragakes \& Lessof, 2003). As a result, regulatory prices for medicines in Russia vary significantly across regions, as each of the 87 regions has its own cost-plus formula for manufacturers, wholesalers and retailers (Zasimova, 2010). Medicines not present on the lists are unregulated and open to free market competition. There are also no distinctions in regulations pertaining to medicine patent status, except for originator medicines manufactured in Russia (Vitale, 2014).

Some of the negative effects resulting from these price regulations, include the reduced investment in the modernization of production for adoption of Good Manufacturing Practice standards (for medicines manufactured in Russia) of medicines on the vital and essential medicinal products, owing to their reduced profitability (Vitale, 2014). There is also a common tendency for wholesalers and retailers to firstly; increase the prices of unregulated medicines to recover profits lost to vital and essential medicinal products and secondly to reduce the circulation of cheap medicinal products. Both of which contribute to increased population expenses for medicines.

The number of medicines included on reimbursement lists are likely to increase in the future. This however does not necessarily relay positive news for all pharmaceutical manufacturers, as prices of these medicine are generally low, remain mostly constant and may not necessitate significantly increase volumes, as patients still purchase those drugs privately (Reinaud, 2013). On the other hand, presence on various lists, can creates advantages for individual manufacturers in relation to each other, as many medicines included in the state lists, have no registered analogues. Distributors and suppliers have to apply to these unique manufacturers or to a representative office in Russia for exclusive distribution rights which may lead to restriction of competition (Vitale, 2014).

Furthermore, the healthcare system in Russia, is often characterized by situations where patients themselves are often the primary buyers of drugs (Aston Consulting, 2012). They often make uniformed medicine choices based largely on advertising. There have been documented cases where firms have inappropriately interacted with public consumers, doctors and pharmacist to stimulate product sales by providing significant discounts and bonuses for its distribution (Vitale, 2014). This has led to manufacturers investing more money into product promotion and sales, instead of investing in product development and innovation, which is a feature lacking in the Russian pharmaceutical industry (Deloitte, 2015).

\subsection{India}

In India, government has increased funding toward the public sector. Firstly, via the National Rural Health Mission, which focuses on primary care and secondly, through the establishment of government insurance schemes that cover hospital care at empanelled public and private hospitals for the poor (Rao, Petrosyan, Araujo, \& McIntyre, 2014).

The Indian Pharmaceutical market is ranked as the 3 rd largest pharmaceutical market in terms of volume and $10^{\text {th }}$ largest in terms of value, contributing towards $10 \%$ of global medicine production (India Brand Equity Foundation, 2016).

Pharmaceutical pricing in India is controlled by the Drug Price Control Order (DPCO), 1995, which is supervised by the National Pharmaceutical Pricing Authority (NPPA) (Vashisth, Singh, \& Nanda, 2012). Prior to 2013, the 
DPCO 1995 controlled the pricing of 74 bulk medicines which were fixed on the basis of manufacturing costs declared by the manufacturers. In 2013, The new DPCO 2013 granted authority to the NPPA to regulate prices of 348 essential drugs (covering close to $30 \%$ of the total domestic market) under the National List of Essential Medicines (NLEM) through a market-based price mechanism (Subramanian, Mutyal, \& Nechamkin, 2014). Under the policy, the ceiling price for each drug under control would be fixed at the weighted average price of brands that have more than $1 \%$ market share. According to the NPPA, trade margins previously estimated at $10 \%$ and $20 \%$ for wholesalers and retailers respectively were now fixed at $8 \%$ for wholesaler and the retail margin at $16 \%$ (Subramanian, Mutyal, \& Nechamkin, 2014). Firms are fee to set maximum retail prices, for medicines that are not under price control, however the NPPA will intervene if drugs have significant sales and where the annual price increases by more than $10 \%$ (Guennif \& Ramani, 2010).

India's emerging market, however is not without its fair share of challenges and shortfalls. Firstly, despite the development of pricing regulations and polices, the country still struggles with issues of proper enforcement. This in part owes to the division of regulatory powers between members within the central and state government. Hence the drug regulatory system lacks independence, is under-staffed and inadequately rigorous, which retards effective running of the regulatory system (Vashisth, Singh, \& Nanda, 2012).

The government has initiated steps to regulate the price of patented medicines and medical devices through a system of reference pricing based on prevailing practices in other 'comparable' countries. The proposal was to link the domestic rate with those at which governments in the United Kingdom, France, Canada, Australia and New Zealand purchase drugs from the company that holds the patent (Sidhartha, 2014). The actual price was to be linked to the purchasing power in India.

\subsection{China}

China's reform toward UHC is founded on the premise of improving primary care services, increasing insurance coverage, and moving away from using patients as a source of financing. China is the second largest pharmaceutical market in the world, with medicine pricing being one of the most rapidly evolving aspects in Chinese policy development (Mossialos, Ge, Hu, \& Wang, 2016).

In China medicine pricing is fragmented, being managed by both central and provincial governments. The Chinese Government reimburses medicines listed on one of two major reimbursements lists: the Essential Drug List (EDL) or the larger National Reimbursable Drug List (NRDL) which are periodically revised to include new medicines (Mossialos, Ge, Hu, \& Wang, 2016). The highly de-centralized structure of the healthcare system, has meant that each province typically maintains a provincial formulary, which differs in scope and the levels of reimbursement offered. The market prices of medicines are freely determined by manufacturers, unless it is included in either list or other government-subsidized program (Mossialos, Ge, Hu, \& Wang, 2016). The highly fragmented system has often resulted in situations of conflicting priorities between provinces and national objectives, and poor coordination has created barriers to policy formulation and implementation, leading to dramatic differences in actual policy implementation (Deloitte, 2015).

The healthcare system relies heavily on cash and out-of-pocket payments made by patients. This typically occurs at hospitals which rely on prescriptions and the sale of pharmaceuticals as a profit centre, thus contributing to high prices and widespread over-prescription (Sun et al., 2008). This situation has resulted in China reporting one of the highest profit margins in the world as mark-ups on pharmaceuticals average $70 \%$ over the ex-manufacturers price (Mossialos, Ge, Hu, \& Wang, 2016). The National Development and Reform Commission (NDRC) has thus set out to reduce the reliance of hospitals on drug prescriptions as a source of income by implementing the Essential Drug List. The prices of all medicines on the list, are fixed with no commissions being paid for their prescription. The effect of this being a 30-50\% reduction in the cost of inpatient and outpatient care (Deloitte, 2014).

Until 1 June 2015 the Chinese government directly participated in determining the prices of reimbursable drugs. This was predominantly achieved through setting ceiling retail prices commissioned by the NDRC. The NDRC set the exact retail price for select listed medicines, the maximum retail price or price caps for the remaining reimbursable medicines and controlled discounting for certain classes of listed medicines.

On the $1^{\text {st }}$ of June, 2015, a new drug pricing reform ('Opinions on Promoting the Drug Pricing Reform' [2015] No. 904) was initiated to replace the price ceilings (Chen et al., 2016). Drug pricing in China is slowly being transformed from cost-based to clinical value-based pricing, together with a shift from the ceiling retail price to medical insurance payment reference pricing (Chen et al., 2016).This process is being piloted in some provinces since 2014. The reference price is set by the NDRC, Ministry of Human Resources and Social Security which defines the maximum level of payment or reimbursement for each drug class. The difference between the actual 
end price and the reference price will have to be paid by the patient. Thus, competition between pharmaceutical companies supplying high-quality generics and off-patent originators is encouraged with the objective of arriving at rational drug prices. Many elements of the new drug pricing reform remain unknown and will likely depend on the pilot project outcomes.

Tendering has become the primary mechanism by which provinces acquire medications for the EDL and is also used for many NRDL drugs (Mossialos, Ge, Hu, \& Wang, 2016). Drug pricing is largely determined through tendering for off-patent drugs or direct negotiations for patent drugs, with the National Health and Family Planning Commission (NHFPC) as a lead. Guidelines for the tender process are developed nationally, however each province conducts the process separately using different tendering criteria. Government mandates that healthcare institutions purchase majority (around $80 \%$ by value) of their medication from winning tenders in each province (Mossialos, Ge, Hu, \& Wang, 2016).

Most provinces use a "two-envelope" system, (based on quality and secondly price) whilst some provinces, make no distinctions in quality (Mossialos, Ge, Hu, \& Wang, 2016). Whilst the success that tendering has had on lowering EDL drug prices by $25 \%$ on average and over $50 \%$ in some provinces between 2009 and $2010(\mathrm{Hu}, 2013)$, a major criticism of the process is the excessive emphasis that it places on price over quality $(\mathrm{Hu}, 2013)$. Consequently, several manufactures undercut the prices of high quality medicines on the basis of price, by manufacturing with low-quality products, leading to a race to the bottom in terms of drug quality (Mossialos, Ge, $\mathrm{Hu}, \&$ Wang, 2016). Further issues with tendering, is that in majority of provinces, tenders are awarded entirely to one company, which leads to monopolies and potentially shortages if the company runs into any production difficulties (Barber et al. 2013). Local protectionism is also a barrier, as provinces often favour local manufacturers when selecting winning tenders. Finally, the bid price is not related to either purchasing or volume. These shortcomings have led government to revise the bidding procedure, to increase transparency. Additionally improving quality assessments has become one of the most important aspects of the tendering reform (Mossialos, $\mathrm{Ge}, \mathrm{Hu}$, \& Wang, 2016).

Initial patented medicine prices can be freely set by the manufacturers, as medicines can only be listed for medical insurance reimbursement after 2 years of market availability, following which the government controls the maximum retail price (Hu et al., 2015). The introduction of pharmacoeconomic evaluations, and external referencing have also been considered as future drug pricing mechanisms. In July 2015, the NDRC informed multinational corporations that they will be required to provide drug prices in the home country as well as prices in the United Kingdom, France, the Netherlands, 12 other European countries, the United States and markets in Asia and Africa. These prices could potentially inform maximum allowable prices for provincial tenders (Mossialos, Ge, $\mathrm{Hu}, \&$ Wang, 2016).

\subsection{South Africa}

The South African government has committed to introducing a tax-funded National Health Insurance Fund as it progresses toward its 14-year UHC plan (Rao, Petrosyan, Araujo, \& McIntyre, 2014). South Africa, the most recent member of the BRICS alliance, has the largest pharmaceutical market in Sub-Saharan Africa (Deloitte, 2015). Despite constraints in revenue growth, owing to government price regulations and slowing economic growth, the market is still anticipated to grow by an average of $6 \%$ annually, to an estimated $\$ 5.1$ billion by 2018 (Deloitte, 2015).

The South African pharmaceutical market which is the most regulated on the African continent consists of two-tiers i.e. a public and a private sector. Post-apartheid in 1994, pricing regulations in the private sector were geared toward total transparency in the pricing structure of medicines. Prices in the private sector are governed by the Single Exit Price mechanism (SEP), which is a composite of the ex-manufacturer's price, logistics fee and value added tax (VAT) - standardized in South Africa at 14\%. The SEP mandates that manufacturers sell their products at one price to all their customers (other than the State), regardless of the nature of the customer's order size and consumption levels, stipulating regulated maximum annual price increases (Nicolosi \& Gray, 2009; Bodhania, 2007). Under the regulation, manufacturers are allowed to set their SEP, which can be increased on an annual basis to a level determined by the state, and the same price must be offered to all buyers (World Health Organization, 2015). They may, however make several temporary price reductions for competitive reasons (van den Heever, 2012). Discounts, rebates, and other forms of commercial incentives are not permitted in the South African supply chain. However, since its implementation, there was is no documented evidence to suggest that regulating discounts and rebates leads to lower prices. In the public sector, the government procures mass volumes of generic medicines via tender. In the private sector, where the generic market is still growing, the higher prices paid for these products help to subsidize the low-cost generics made available to the public sector (Ngozwana, 
2016).

At the retail level, pharmacists dispensing fees are based on a fixed amount and a percentage component, varied by four bands of the SEP that endeavours to promote the dispensing of cheaper products (Ngozwana, 2016; Gray \& Suleman, 2015).

Under the current SEP regulation, companies of originator medicines still have the freedom to set launch prices, however the Pricing Committee would be responsible for determining annual price increases in accordance with the SEP regulations methodology. As a result, pricing of these medicines remains largely at the discretion of the manufacturer. In this regard, government has proposed to introduce an external reference price system, in which the prices of originator medicines will be compared with those in a basket of countries (Australia, Canada, New Zealand, and Spain, together with South Africa). For generic medicines, the ex-manufacturer price is to be set at least $40 \%$ lower than the existing price of the originator medicine (Taylor, 2007). The process is likely to reduce the SEP of medicines in South Africa and create some transparency of pricing at the ex-manufacturer pricing level. This legislative framework has been in the pipeline since 2006 but has faced stiff lobbying in terms of implementation. If implemented it would reduce originator medicine costs by around 25\% (van den Heever, 2012). In addition to the external reference price, the application of pharmacoeconomics analyses, on a voluntary basis, has also been proposed to determine medicine prices. The latter provision, however requires considerable resources and capacity on the part of the manufacturers to prepare submissions, as well as on the Pricing Committee to critically assess the submissions and make defensible determinations on that basis (Gray \& Suleman, 2015).

The public-sector procurement is based on the National Essential Medicines List. Medicines in the public sector are procured via state tender schemes which are administered by the Central Procurement Unit of the Department of Health. Large purchases by government on behalf of the South African population has resulted in medicines in the public sector being substantially cheaper than in the private sector.

South Africa provides an example of a country making several attempts at regulating medicine pricing, however little information is available about the enforcement or effects of these pricing regulations. The literature does however, echo the difficulties experienced in implementing regulations, which would be an important lesson for countries with lower regulatory and technical capacity considering to implement similar mechanisms. There has been further discussion on additional regulations in the market as South Africa moves toward UHC. Some, however, argue that this will stifle competition and increase prices, while others justify additional regulation as necessary to limit price inflation.

\section{Limitations}

This study would have benefitted from using current pricing data for each country. Lack of data in this regard, makes it difficult to conclusively compare prices. Furthermore, a time series analysis of implemented regulations in each country and medicine prices was not conducted. This would have aided future regulatory development, by identifying the various outcomes of each intervention.

\section{Conclusion}

Whilst BRICS have committed to lowering medicine prices, they have each have used different reforms in hope of achieving this. The comparison of medicine prices conducted in this study reveal, that some countries have been more successful in achieving lower prices than others. However, this finding is not generalizable, and warrants more in-depth studies comparing the prices of medicines from several therapeutic classes, patent groups and presence on various pricing and reimbursement lists. Across the majority of BRICS countries, pricing regulations were only applied to a segment of pharmaceuticals available in the country, i.e. those present on reimbursement lists or other forms of government lists and programs. Medicines excluded from these lists, are open to competition and prices are freely determined by the demand ratio of supply and demand. Hence an important next step for each country, would be to monitor the impact of each regulation on medicine prices to determine if reforms are viable, or if free competition is more successful in lowering prices. As restricting prices in one segment of the market, could result in an increase in medicine prices in another unregulated segment. It was found that only Russian and China, actively monitor retail prices, which is an important initiative that should be conducted by all countries. Amongst BRICS, Russia importantly seems to promote the sale of locally produced medicines, through pricing regulations. This is an important aspect for countries wishing to strengthen local production.

External reference pricing (ERP) which is currently being practiced in Brazil, has gained popularity amongst BRICS. China, India and South Africa have identified the benefits of its use in negotiating and benchmarking medicine prices. These countries have made proposals to adopt this system in the future. ERP is a relatively 
transparent pricing method, and may lead to rapid savings by referencing to low-price countries (Carone, Schwierz $\&$ Xavier, 2012). It should ideally form part of a combination of other price control options, including demand-side polices that promote the rational use of medicines. The general problem that arises with this system of pricing is the difficulty experienced with comparative pricing across countries (Ball, 2011). This includes issues such as differences in pack sizes, strengths and unit prices amongst others. The success of implementing ERP, requires the concomitant use of pharmacoeconomic analyses and other health technology assessments as a tool in decision making and price setting/negotiation (World Health Organization, 2015). This in turn requires an investment in training personnel and equipping them with appropriate technical abilities to develop reports and make informed decisions based on their findings.

An important aspect of reform and regulation development, is to undertake wide-scale consultation with all stakeholders. Such a stance was evident in South Africa, where despite the acrimony attached to reform, consultation helped make the processes and decisions transparent. The lack of transparency in policy development, can also be attributed to regulatory fragmentation, as envisioned government policies do not necessarily translate to what is implemented on the ground. This lack of clarity and divisions in regulatory powers was evident in India, China and Russia.

BRICS have all made attempts at regulating distribution chain mark-ups, with varying degrees. According to WHO, the best way to implement such strategies is to ensure that they form part of a comprehensive system, which opts to use regressive mark-ups rather than fixed percentage marks, as the latter provides for higher-priced products to receive higher net margins (World Health Organization, 2015). The WHO further recommends regulating rebates and discounts, to increase transparency in the distribution chain. South Africa is the only country where the above mentioned are regulated, as they are prohibited. However, in South Africa, increased transparency has not been proven to lower medicine prices. Hence it is important for South Africa to better document this reform, to determine if it indeed is effective, and could serve as a benchmark study for other countries

Brazil, Russia, India, China and South Africa have all embarked on steadily reforming their healthcare and pharmaceutical sectors. All seeming to have cemented their place as global players in the pharmaceutical market, and all forecast for further market growth into the foreseeable future. Each countries evolution has been underpinned by local variations on common challenges (Ezziane, 2014). Most notably being the mutual need to increase medicine accessibility and reduce costs. Despite the common drivers behind legislature and policy implementation, progress in these areas has not happened in synchronicity within each country, each facing their individual hurdles through the process. It is envisaged that, from this coalition of information obtained from the results of the online survey, greater lessons can be learnt from each country to improve the outcomes for each individual country and create an opportunity for pharmaceutical growth.

\section{Funding}

This work is based on the research supported in part by the National Research Foundation of South Africa for the grant, Unique Grant No. 99238.

Research reported in this publication was supported by the Fogarty International Centre (FIC), National Institutes of Health Common Fund, Office of Strategic Coordination, Office of the Director (NIH CF/OSC/OD), Office of AIDS Research, Office of the Director (OAR/OD/NIH), National Institute of Mental Health of the NIH (NIMH/NIH) under Award Number D43TW010131. The content is solely the responsibility of the authors and does not necessarily represent the official views of the NIH.

\section{Competing Interests Statement}

The authors declare that there are no competing or potential conflicts of interest.

\section{References}

Aston Consulting. (2012). Russian pharmaceutical market: Current review and future outlook until 2020. Opportunities for Swiss companies. Retrieved May 1, 2016, from http://www.sge.com/sites/default/files/private_files/BBK_Russian_Pharmaceutical_Market_Study.pdf

Barber., S. L., Huang, B, Santoso, B., Laing, R., Paris, V., \& Wu, C. (2013). The reform of the essential medicines system in China: A comprehensive approach to universal coverage. Journal of Global Health, 3(1), 010303. https://doi.org/10.7189/jogh.03.010303

Ball, D. (2011). The regulation of mark-ups in the pharmaceutical supply chain. WHO/HAI Project on medicine prices and availability, Review series on pharmaceutical pricing policies and interventions, Working paper, 3. 
Retrieved August 21, 2016, from http://haiweb.org/wp-content/uploads/2015/07/Working-Paper-3-Regulation-of-Mark-ups.pdf

Bertoldi, A. D., Helfer, A. P., Camargo, A. L., Tavares, N. U., \& Kanavos, P. (2012). Is the Brazilian pharmaceutical policy ensuring population access to essential medicines?. Globalization and Health, 8(1), 1. https://doi.org/10.1186/1744-8603-8-6

Bodhania, M. (2007). Pharmaceutical sector presentation for private health sector Indaba. Retrieved July 8, 2016, http://www.slideserve.com/moeshe/pharmaceutical-sector-presentation-for-private-health-sector-indaba

Cameron, A., Ewen, M., Ross-Degnan, D., Ball, D., \& Laing, R. (2009). Medicine prices, availability, and affordability in 36 developing and middle-income countries: a secondary analysis. The Lancet, 373(9659), 240-249. https://doi.org/10.1016/S0140-6736(08)61762-6

Carone, G., Schwierz, C., \& Xavier, A. (2012). Cost-containment policies in public pharmaceutical spending in the EU. https://doi.org/10.2139/ssrn.2161803

Chen, Y., Hu, S., Dong, P., Kornfeld, Å., Jaros, P., Yan, J., Ma, F., \& Toumi, M. (2016). Drug Pricing Reform in China: Analysis of piloted approaches and potential impact of the reform. Journal of Market Access \& Health Policy, 4. Retrieved July 8, 2016, from http://www.jmahp.net/index.php/jmahp/article/view/30458

Deloitte. (2014). The next phase: Opportunities in China's pharmaceuticals market. Retrieved May 10, 2016, http://www2.deloitte.com/content/dam/Deloitte/ch/Documents/life-sciences-health-care/ch_Studie_Pharma ceutical_China_05052014.pdf

Deloitte. (2015). Development trends and practical aspects of the Russian pharmaceutical industry-2015. Survey results. Retrieved July 13, 2016, from http://www2.deloitte.com/content/dam/Deloitte/ru/Documents/life-sciences-health-care/russian-pharmaceut ical-industry-2015.pdf

Deloitte. (2015). Life sciences outlook South Africa. Retrieved July 8, 2016, http://www2.deloitte.com/content/dam/Deloitte/global/Documents/Life-Sciences-Health-Care/gx-lshc-2015 -life-sciences-report-south-africa.pdf

EMIS. (2014). Pharmaceutical sector Brazil. Retrieved July 13, 2016, from https://www.emis.com/sites/default/files/EMIS\%20Insight\%20\%20Brazil\%20Pharmaceutical\%20Sector.pd $\mathrm{f}$

Ezziane, Z. (2014). Essential drugs production in Brazil, Russia, India, China and South Africa (BRICS): opportunities and challenges. International Journal of Health Policy and Management, 3(7), 365-370. https://doi.org/10.15171/ijhpm.2014.118

Guennif, S., \& Ramani, S. (2010). Catching up in pharmaceuticals: A comparative study of India and Brazil. Retrieved August 1, 2016, Available from: https://hal.archives-ouvertes.fr/hal-00632439/document

Gray, A., \& Suleman, F. (2015). Pharmaceutical pricing in South Africa. In Pharmaceutical prices in the 21st century (pp. 251-265). Springer International Publishing.

Health Action International. (2010). Life-saving insulin largely unaffordable-a one day snapshot of the price of insulin across 60 countries. Retrieved July 13, 2016, from www.haiweb.org/medicineprices/07072010/Global_briefing_note_FINAL.pdf

Hu, S. (2013). Essential medicine policy in China: Pros and cons. Journal of Medical Economics, 16(2), 289-294. https://doi.org/10.3111/13696998.2012.751176

Hu, S., Zhang, Y., He, J., Du, L., Xu, M., Xie, C., Peng, Y., \& Wang, L. (2015). A case study of pharmaceutical pricing in China: Setting the price for off-patent originators. Applied Health Economics and Health Policy, 13(1), 13-20. https://doi.org/10.1007/s40258-014-0150-5

IMS Health. (2015). Brazil: A complex market demanding substantial commitment. IMS Pharma Pricing \& Reimbursement, 20(1), 10-13.

India Brand Equity Foundation. (2016). Indian pharmaceutical industry. Retrieved May 1, 2016, http://www.ibef.org/industry/pharmaceutical-india.aspx

Keeton, C. (2014). BRICS seek value for money as health-care costs rise. Bulletin of the World Health Organization, 92(6), 392. https://doi.org/10.2471/BLT.14.020614

Kohler, J. C., Mitsakakis, N., Saadat, F., Byng, D., \& Martinez, M. G. (2015). Does pharmaceutical pricing 
transparency matter? Examining Brazil's public procurement system. Globalization and Health, 11(1), 1. https://doi.org/10.1186/s12992-015-0118-8

Mossialos, E., Ge, Y., Hu, J., \& Wang, L. (2016). Pharmaceutical policy in China: Challenges and opportunities for reform. $\quad$ Retrieved May 10, 2016, http://www.lse.ac.uk/LSEHealthAndSocialCare/pdf/China-pharma-book-web.pdf

Nicolosi, E., \& Gray, A. (2009). Potential cost savings from generic medicines-protecting the prescribed minimum benefits. South African Family Practice, 51(1), 59-63. https://doi.org/10.1080/20786204.2009.10873809

Ngozwana, S. (2016). Policies to control prices of medicines: Does the South African experience have lessons for other African countries? In Making medicines in Africa (pp. 203-223). Palgrave Macmillan UK.

Pharmaceutical Market Assessment and PRMA in CEE, CIS, Asia. (2013, March, 22). Russia: Pricing in the pharmaceutical industry. Retrieved August 9, 2016, from http://cispharma.blogspot.co.za/2013/03/russia-pricing-in-pharmaceutical.html

Pricewaterhouse Coopers. (2013). Pharmaceutical industry in Brazil. Retrieved May 1, 2016 from https://www.pwc.com.br/pt/publicacoes/setores-atividade/assets/saude/pharma-13-ingles.pdf

Rägo, L., \& Santoso, B. (2008). Drug regulation: History, present and future. Drug benefits and risks: International textbook of clinical pharmacology (2nd ed.).

Rao, K. D., Petrosyan, V., Araujo, E. C., \& McIntyre, D. (2014). Progress towards universal health coverage in BRICS: Translating economic growth into better health. Bulletin of the World Health Organization, 92(6), 429-435. https://doi.org/10.2471/BLT.13.127951

Reinaud, F. (2013). Russia's improved pharmaceuticals market access and price control? Retrieved May 11, 2016, http://blog.ihs.com/russias-improved-pharmaceuticals-market-access-and-price-control

Sidhartha. (2014). Patented drugs face price caps. The Times of India. Retrieved May 10, 2016, http://timesofindia.indiatimes.com/business/india-business/Patented-drugs-face-price-caps/articleshow/2943 $0775 . \mathrm{cms}$

Subramanian, R., Mutyal, N., \& Nechamkin, E. (2014). Are market-based pharmaceutical price controls the new reality in India? Three strategic implications for Pharma and Biotech in India. Retrieved June 1, 2016, https://www.simon-kucher.com/sites/default/files/are_marketbased_pharmaceutical_price_controls_the_ne w_reality_in_india_simon-kucher_april_2014.pdf

Sun, J., Boing, A. C., Silveira, M., Bertoldi, A. D., Ziganshina, L. E., Khaziakhmetova, V. N., ... Suleman, F. (2014). Efforts to secure universal access to HIV/AIDS treatment: a comparison of BRICS countries. Journal of Evidence - Based Medicine, 7(1), 2-21. https://doi.org/10.1111/jebm.12081

Sun, Q., Santoro, M. A., Meng, Q., Liu, C., \& Eggleston, K. (2008). Pharmaceutical policy in China. Health Affairs, 27(4), 1042-1050. https://doi.org/10.1377/hlthaff.27.4.1042

Taylor, B. (2007). Rationing of Medicines and Health Care Technology. South African Health Review, 123-138.

Tragakes, E., \& Lessof, S. (2003). Health care systems in transition: Russian Federation. In Health care systems in transition: Russian Federation. Retrieved May 1, 2016, from http://www.euro.who.int/_data/assets/pdf_file/0005/95936/e81966.pdf

Ultrapar. Extra Farma. Retrieved July 13, 2016, from http://www.ultra.com.br/show.aspx?idCanal=Tl10W0HJ3TuveHJenoTBYQ

van den Heever, A. (2012). Review of competition in the South African health system. Pretoria: Competition Commission.

Vashisth, S., Singh, G., \& Nanda, A. (2012). A comparative study of regulatory trends of pharmaceuticals in Brazil, Russia, India and China (BRIC) countries. Journal of Generic Medicines: The Business Journal for the Generic Medicines Sector, 9(3), 128-143. https://doi.org/10.1177/1741134312459187

Vitale, C. (2014). Competition issues in the distribution of pharmaceuticals: Contribution from the Russian Federation. $\quad$ Retrieved July $\quad 1, \quad 2016$, from http://www.oecd.org/officialdocuments/publicdisplaydocumentpdf/?cote=DAF/COMP/GF/WD(2014)33\&d ocLanguage $=$ En

World Health Organization. (2015). WHO guideline on country pharmaceutical pricing policies. Retrieved May 1, 
2016, http://apps.who.int/medicinedocs/documents/s21016en/s21016en.pdf

Zasimova, L. (2010). Public policy and access to new drugs: Evidence from Russian pharmaceutical market. Electronic Publications of Pan-European Institute, 2, 2010.

\section{Copyrights}

Copyright for this article is retained by the author(s), with first publication rights granted to the journal.

This is an open-access article distributed under the terms and conditions of the Creative Commons Attribution license (http://creativecommons.org/licenses/by/4.0/). 